\title{
Importance of Building Energy Efficiency Towards National and Regional Energy Targets
}

\author{
Can B. Aktaş
}

\begin{abstract}
The buildings sector in the EU consumes 40\% of energy and is responsible for $36 \%$ of $\mathrm{CO}_{2}$ emissions. With growing public interest on the subject, there have been several EU policies developed to curb impacts. Statistical analysis conducted in the case study indicates an increase in both total and buildings' energy consumption trends leading up to 2030, with total energy consumption having an expected value of $40 \%$ increase and building energy consumption having an expected value of $33 \%$ increase. Analysis results indicate that building energy consumption could be maintained at current levels if a proactive approach is embraced. Focusing solely on buildings' energy consumption does not solve national or regional energy problems, but neglecting them altogether prevents significant gains to be made. Building energy efficiency is not the solution by itself to achieve energy goals in EU, but is an important contributor toward the solution.
\end{abstract}

\section{Introduction}

In the EU, buildings are responsible for approximately $40 \%$ of energy consumption, and $36 \%$ of $\mathrm{CO}_{2}$ emissions. Approximately $40 \%$ of residential buildings in EU are dated pre-1960, with another $45 \%$ from between 1960 and 1990 and did not undergo major renovation since then. Currently, almost $75 \%$ of the building stock in the EU is reported to be energy inefficient [1]. Building energy efficiency measures are known to generate economic, societal, and environmental benefits. They also stimulate the economy, in particular the construction industry which generates about $9 \%$ of EU's GDP and directly accounts for 18 million jobs. Especially SMEs are known to benefit from building energy efficiency measures as they contribute to more than $70 \%$ of the value added in the EU building sector [1].

Existing EU policies demonstrate the timeliness of the subject as successive EU policies regarding building energy efficiency have been put forth in recent years

C. B. Aktaş (ه)

Department of Civil Engineering, TED University, Ankara, Turkey

e-mail: can.aktas@tedu.edu.tr 
including the 2010 Energy Performance of Buildings Directive and the 2012 Energy Efficiency Directive. The former directive has a 2020 strategy of making new construction nearly zero-emission buildings [2]. Hence, there is urgency toward further action as goals are already set to curb energy consumption and associated emissions.

Sandberg et al. [3] demonstrate that the intended EU energy efficiency goals cannot be met if the best available energy efficiency measures are not applied when existing dwellings undergo renovation during their lifetime. While existing building energy codes and regulations are a step forward in the right direction, they have not proven to be sufficient to achieve desired efficiency gains. Furthermore, developers and consumers alike have been shown to interpret meeting the minimum requirements set by the code as sufficient warranty for the energy efficiency of the building, whereas the code rarely represents the optimal point of efficiency $[4,5]$. There have been developments in numerous building efficiency technologies to reduce energy consumption in buildings, but their implementation has been lagging mostly due to a lack of knowledge or awareness of their potential impacts, which could be significant considering the extensive lifetime of residential buildings.

The goal of this study is to identify the extent building energy efficiency can play a role toward meeting national and regional energy targets. For that purpose, total energy consumption together with the building sector's share has been analyzed together with forecasts for the near future in line with EU Directives timeline.

Data on Turkey was analyzed as a case in point, as it is one of the fastest growing economies in the EU region as well as having one of the highest total energy demand in the region. Turkey's population grew from 56.5 million in 1990 to 71.5 million in 2008. In addition to population growth, Turkey's urbanization rate has also increased from $52.9 \%$ to $74.9 \%$ during those years. As a result of these population movements, the number of buildings and consequently energy consumption in buildings increased rapidly [6]. As a result of the developing economy and increasing urbanization rate, electricity consumption has tripled between 1990 and 2008 and reached 198 TWh. Furthermore, Turkey has experienced the highest increase in energy demand in the past 10 years among OECD countries, and only second after China globally. Current expectations are that the trend will continue in short and medium terms $[6,7]$.

\section{Turkey's Total and Sectoral Energy Demand}

Between 1972 and 2017, Turkey's total energy consumption rose from 20 million ton petrol equivalent (TPE) to 111 million TPE, indicating a 5.5-fold increase in total energy consumption within 45 years. Figure 1 presents total and sectoral energy consumption trends, both via historical data, as well as forecasted levels of consumption via a statistical analysis that has been carried out. It can be observed that exponential distribution provides the best fit to past data with the indicated $\mathrm{R}^{2}$ values, as compared to a linear trend [8]. 


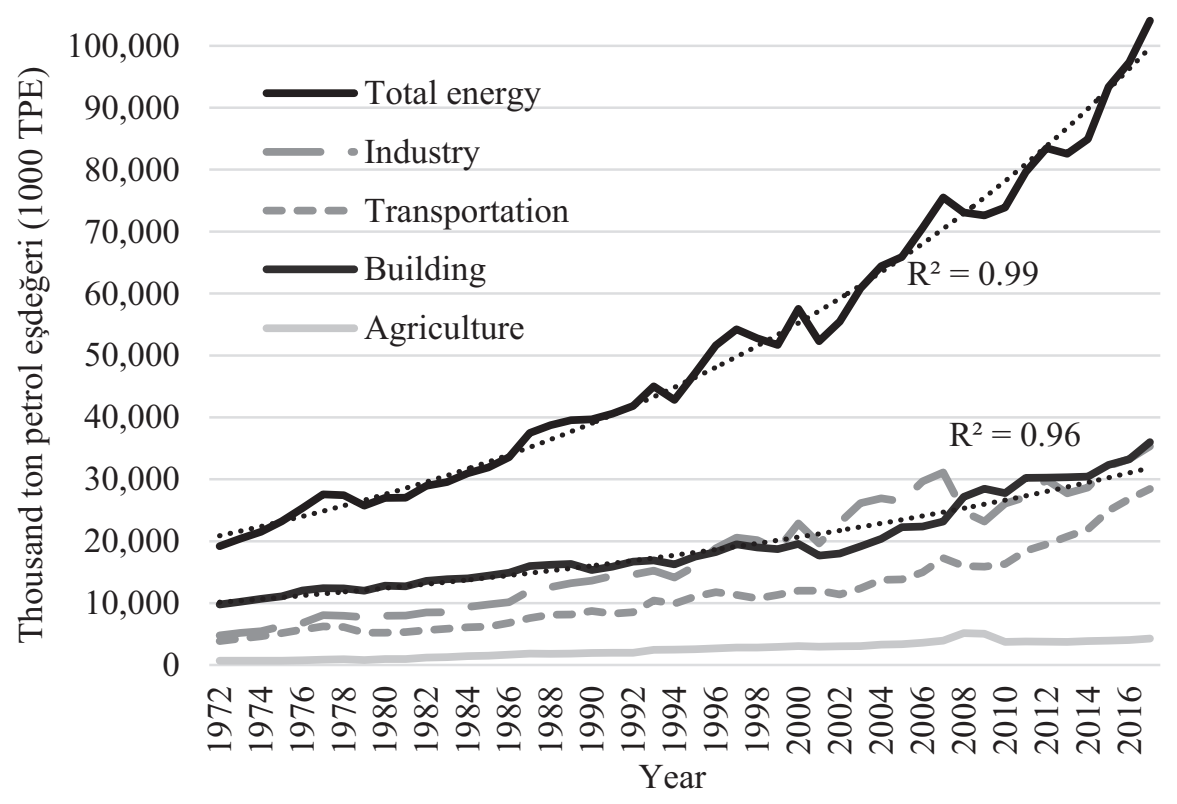

Fig. 1 Total and sectoral energy consumption in Turkey between 1972 and 2017 [8]

Forecasting methods up to the year 2030 have been carried out by using statistical methods. The tool of choice was "Crystal Ball" software. Forecast assessment carried out using the autoregressive integrated moving average (ARIMA) model provided a $95 \%$ confidence interval for the expected energy consumption level by 2030. In this context, total consumption and consumption in buildings are presented separately in Figs. 2 and 3 for closer examination of the range, and their implications.

The average value of expected total energy consumption in 2030 is 152 million TPE, and with $95 \%$ probability consumption is expected to be between 122 and 182 million TPE. The average value indicates an increase of $40 \%$ should be expected compared to 2017 levels. Considering the confidence interval, an increase of $10-65 \%$ may be expected by 2030 with a probability of $95 \%$. What should also be emphasized is that it is very unlikely that total energy consumption will remain constant, let alone decrease, in the next decade in Turkey [8].

The average value of forecasted building energy consumption is 48 million TPE for 2030 . The $95 \%$ confidence interval indicates that consumption may be expected to be in between 37 and 59 million TPE. These values indicate that the average consumption will increase by $33 \%$ from the 36 million TPE level in 2017, will remain flat in the best-case scenario, and will increase by $64 \%$ in case of a rapid increase. 


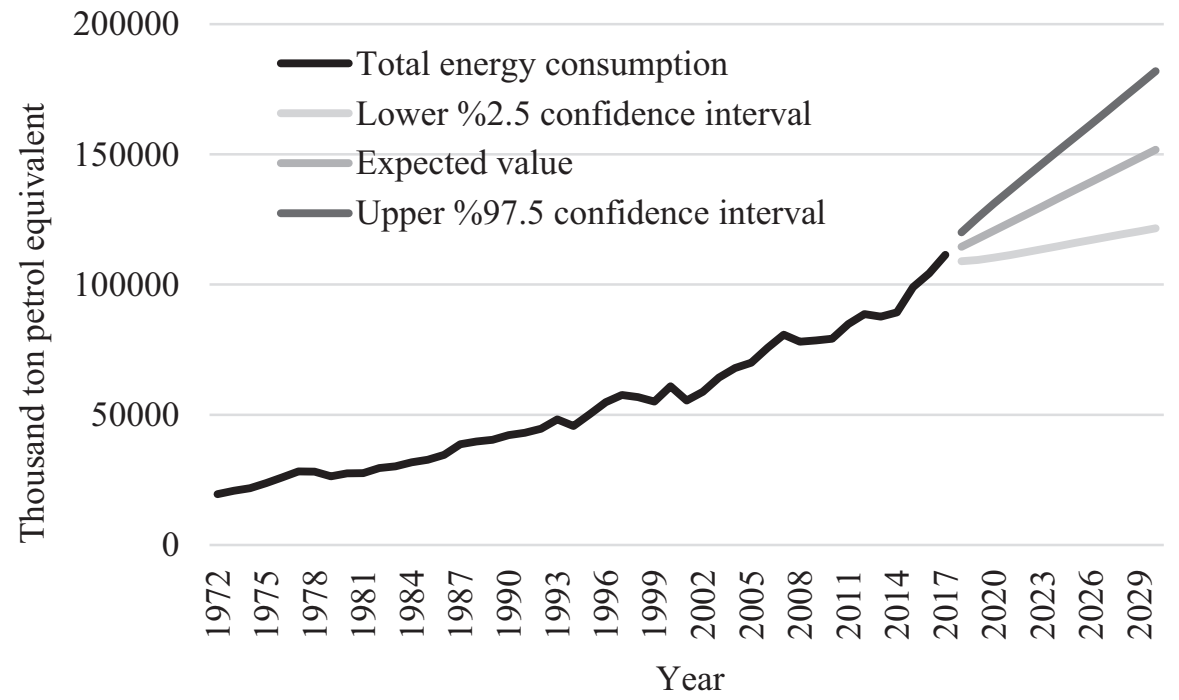

Fig. 2 Average estimated value of the total energy consumption forecasted for 2030 together with its $95 \%$ confidence interval [8]

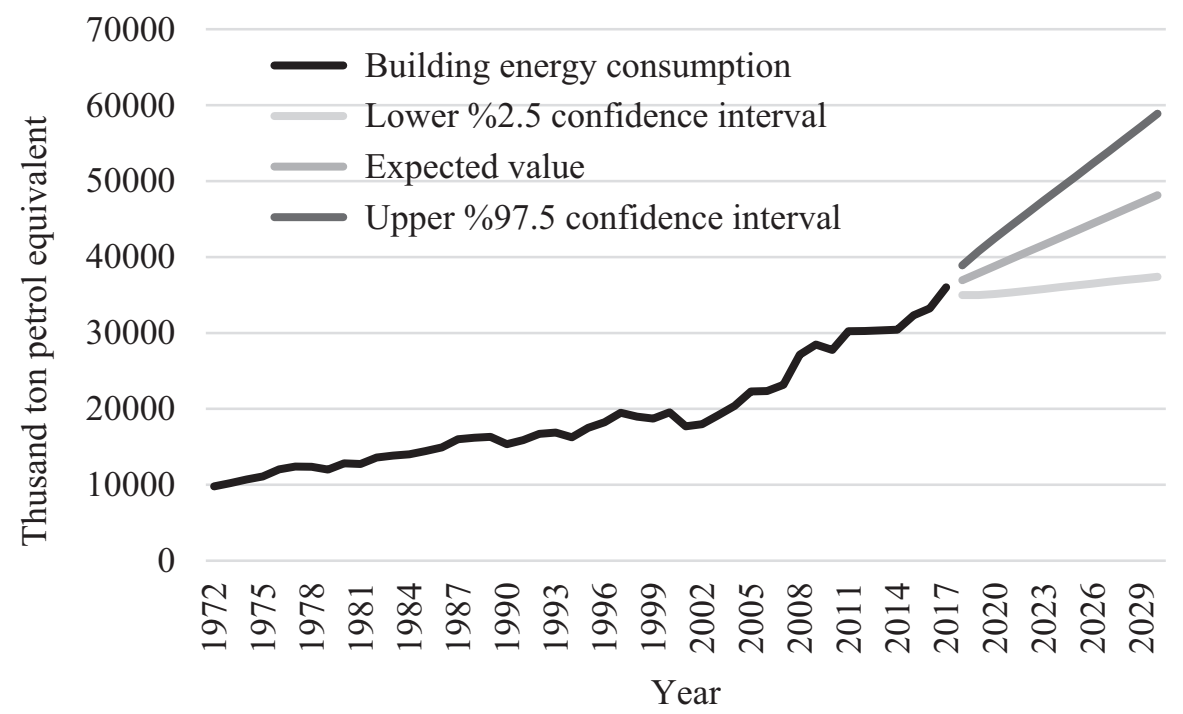

Fig. 3 Average estimated value of building energy consumption forecasted for 2030 together with its $95 \%$ confidence interval [8] 


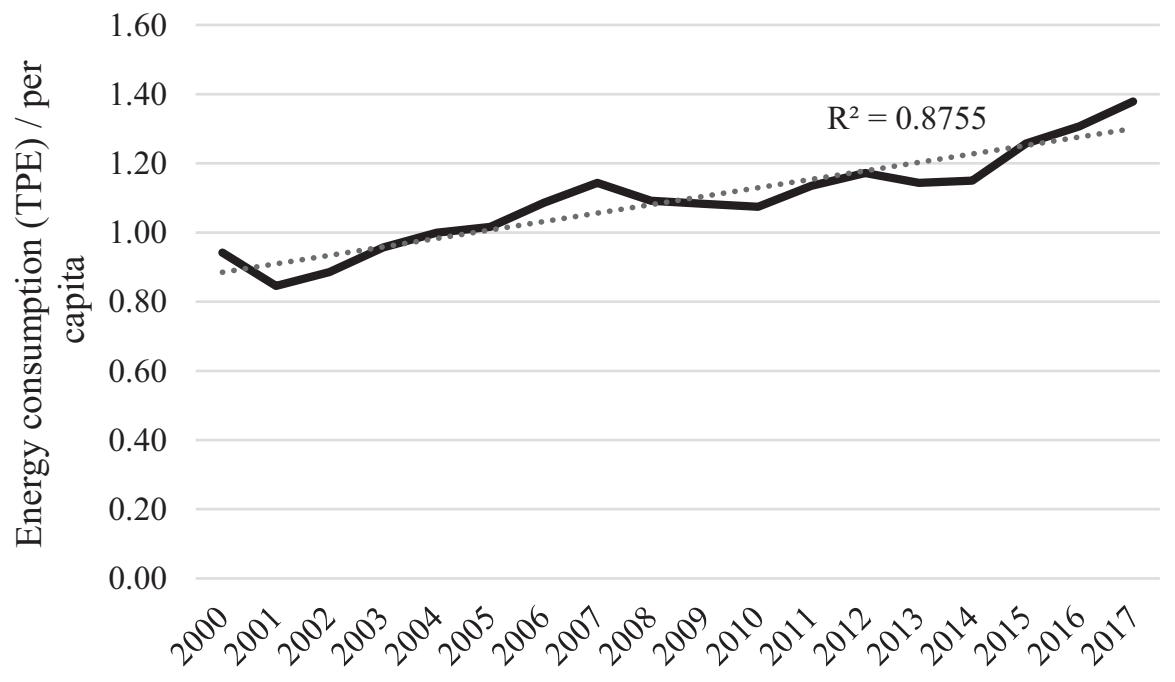

Fig. 4 Energy consumption per capita in Turkey between 2000 and 2017 in TPE [9-10]

\subsection{Energy Consumption Per Capita}

Energy consumption per capita is important both for forecasting energy consumption levels and for comparisons among countries. For this reason, per capita energy consumption was analyzed and presented in Fig. 4. Since annual population information could not be obtained from reliable sources before 2000, the evaluation was limited to 2000-2017. Results indicate that in addition to an increase in population in Turkey, per capita energy consumption has also increased consistently together, leading to an even more rapid increase in total energy consumption. This trend overlaps with those seen in other countries in the EU and elsewhere.

\subsection{Factors that Contribute to Total and Building Energy Consumption}

The most frequently studied factor looking into the causality of energy consumption of countries is economic activity or gross domestic product (GDP). There are several detailed studies on the subject in academic literature [11-12]. However, as part of the case study, it was deemed valuable to not only analyze GDP but also investigate the correlation between energy consumption and other pertinent factors. Among the factors analyzed were factors such as population, foreign exchange rate index, and oil price index.

The correlation between the above listed factors with energy consumption was evaluated using the Pearson correlation coefficient and results presented in Table 1. 
Table 1 Correlation between total energy consumption and analyzed factors. Presented values are Pearson correlation coefficients [13-16]

\begin{tabular}{l|l|l}
\hline & Total energy consumption & Building energy consumption \\
\hline GDP index $(1972=100)$ & 0.989 & 0.985 \\
\hline Building energy consumption & 0.979 & - \\
\hline Population & 0.968 & 0.976 \\
\hline Foreign exchange index & 0.924 & 0.912 \\
\hline Oil price index & 0.747 & 0.780 \\
\hline
\end{tabular}

The Pearson correlation coefficient is a statistical method frequently used to determine the linear correlation between two variables. Results are between -1 and 1 , and as the values increase, it indicates a stronger correlation between the variables. A positive or negative result indicates direct or indirect correlation, respectively. Zero value indicates that no correlation was detected among the variables.

In agreement with existing literature, the case study also found GDP to be the main factor correlated with both total and building energy consumption. The fact that this analysis was based on a time span of 45 years may indicate that policies or studies aiming to forecast future energy consumption should pay close attention to GDP. Another outcome of the analysis is the revelation on the close correlation between total and building energy use. At least in the past 45 years, the two can be said to have moved together.

\section{Role of Building Energy Efficiency Targets Towards National Goals}

In order to maintain the current national energy consumption level, energy efficiency policies will need to be developed, enacted, and regulated in order to minimize a further increase in energy consumption. As was discussed in Sect. 2, the expected value of total energy consumption in 2030 is 152 million TPE with a $95 \%$ confidence interval of 122-182 million TPE. For buildings, the expected value was 48 million TPE with a 95\% confidence interval of 37-59 million TPE.

The abovementioned statistical values were taken as a basis in determining the energy efficiency targets required for the residences to stabilize or reduce the national energy consumption. In this context, the aim is to reduce the energy consumption level as much as possible with effective policies and techniques. Existing data and assessment of Turkey's total energy levels to maintain the level of 2017 indicate that this goal is not achievable only through improving the energy efficiency of buildings. The expected increase in total energy consumption of 41 million TPE is higher than the entire energy consumed by buildings in 2017. Therefore, it seems unlikely that total energy consumption will stabilize or decrease in the short term. Increasing population and per capita energy consumption values also support this result. What needs to be done is to establish and implement effective 
policies toward these targets with the assumption that the environmental, social, and economic goals and priorities will be determined, and energy consumption will increase. While setting official goals and targets aiming for stabilizing or reducing total national energy consumption, statistical analysis of past policies and practices of the past 45 years indicates that such goals may be beyond reach at least for certain countries. They may still have motivational value, but lack a strong scientific basis unless drastic technological changes are mandated and implemented.

However, when energy consumption of buildings is examined, it seems possible that the increase may be reversed with a proactive approach. The stated expected value assumes that the methods and techniques applied to date will continue to change at the same rate moving forward. However, increasing energy consumption in buildings can be prevented with effective policies and methods. The numerical target determined for this purpose is an additional 25\% energy efficiency in buildings based on their current state of energy consumption. However, this strategy should be applied not only to new buildings but also to existing ones, as failure to improve the performance of existing buildings mostly negates any significant gains that may be achieved through new buildings alone. It is not possible to reach the desired energy consumption target set by the EU Directive on buildings by 2030 with policies targeting only the construction of new buildings. Ultimately, even though focusing solely on buildings' energy consumption do not solve national or regional energy problems, due to the share of energy consumed in buildings, neglecting them altogether prevents significant gains to be made. Therefore, building energy efficiency is not the solution by itself to achieve regional energy goals, but is an important contributor toward the solution.

The analysis described herein was based on a case study of Turkey. The reasons for its selection were explained previously and include the fact that Turkey is one of the fastest growing economies in the region and has one of the highest energy demands. However, the conclusions from the analysis do not stay limited to one country, and similar results may be expected for the EU region in general as the underlying principles and factors that affect energy consumption remain the same. Therefore, the presented case study sheds light on the influence and potential impact of building energy use toward national and regional energy goals.

\section{Conclusions}

The buildings sector in the EU is significant when dealing with energy or environmental issues as buildings consume $40 \%$ of energy and are responsible for a comparable amount of greenhouse gas emissions. On the other hand, $85 \%$ of buildings in the EU are built before 1990, with $40 \%$ built before 1960. This is a problem as well as an advantage: energy-inefficient homes have led to higher than required energy consumption in the EU region; but potential gains to be made by employing efficiency measures are significant. With growing public interest on the subject, 
there have been several EU projects, guidelines, and policies developed to curb energy consumption and associated emissions.

Turkey is used as a case study in this study as the country has one of the fastest growing economies in the region, and also has a high energy demand growth, which is the central theme of the study. Both total energy consumption and building energy consumption in Turkey have increased exponentially in the past 45 years, although building energy consumption could possibly be represented by a linear trendline as well. This is positive as it indicates a certain degree of energy efficiency measures taking hold in the buildings sector.

Statistical analysis conducted in the analyzed case study indicates an increase in both total and buildings' energy consumption trends leading up to 2030, with total energy consumption having an expected value of $40 \%$ increase with a $95 \%$ confidence interval of 10-65\%, and building energy consumption having an expected value of $33 \%$ and a $95 \%$ confidence interval of 3-64\%. Analysis results indicate that total energy consumption should be expected to increase even in the best-case scenario, but building energy consumption could be maintained at current levels if a proactive approach is embraced.

Multiple factors were analyzed to test correlation with energy consumption. Among the variables analyzed, GDP was found to be highly correlated with energy consumption both for total and for building energy consumption with a Pearson correlation coefficient of 0.99 for both. This fact could provide a quick way of estimating future changes in energy consumption in other countries and regions as well.

Results of the study indicate that it is not possible to reach the desired energy consumption target set by the EU Directive on buildings by 2030 with policies targeting only the construction of new buildings. Ultimately, even though focusing solely on buildings' energy consumption does not by themselves solve national or regional energy problems, due to the share of energy consumed in buildings, neglecting them altogether prevents significant gains to be made. Therefore, building energy efficiency is not the solution by itself to achieve regional energy goals, but is an important contributor toward the solution.

\section{References}

1. European Commission - Buildings. https://ec.europa.eu/energy/en/topics/energy-efficiency/ buildings

2. Energy Performance of Buildings Directive, Directive 2010/31/EU of the European Parliament and of the Council of 19 May 2010 on the energy performance of buildings, https://eur-lex. europa.eu/legal-content/EN/TXT/HTML/?uri=LEGISSUM:en0021\&from=EN\&isLeg issum=true

3. Sandberg, N. H., Sartori, I., Heidrich, O., et al. (2016). Dynamic building stock modelling: Application to 11 European countries to support the energy efficiency and retrofit ambitions of the EU. Energy and Buildings, 132, 26-38. https://doi.org/10.1016/j.enbuild.2016.05.100

4. Laustsen, J. (2008). Energy efficiency requirements in building codes, energy efficiency policies for new buildings. International Energy Agency. 
5. Morrissey, J., \& Horne, R. E. (2011). Life cycle cost implications of energy efficiency measures in new residential buildings. Energy and Buildings, 43(4), 915-924. https://doi.org/10.1016/j. enbuild.2010.12.013

6. UNDP. (2010). Promoting energy efficiency in buildings. United Nations Development Programme.

7. MFA. (2017). Turkey's energy profile and strategy. Ministry of Foreign Affairs, http://www. mfa.gov.tr/turkeys-energy-strategy.en.mfa. Accessed 01 June 2018.

8. Aktaş, C. B. (2019). Ulusal enerji tüketiminin değerlendirmesi ve istatistiksel tahmini. Bitlis Eren Üniversitesi Fen Bilimleri Dergisi, 8(4), 1422-1431. https://doi.org/10.17798/ bitlisfen.542963

9. Enerji İşleri Genel Müdürlüğü. İstatistikler - Denge Tabloları. http://www.eigm.gov.tr/tr-TR/ Denge-Tablolari/Denge-Tablolari?page=1. T.C. Enerji ve Tabii Kaynaklar Bakanlığı. Accessed 01 July 2018.

10. TÜIK. Temel İstatistikler, Nüfus ve Demografi - Nüfus İstatistikleri - Ylllara Göre İl Nüfuslart 2000-2018. http://www.tuik.gov.tr/UstMenu.do?metod=temelist. Türkiye İstatistik Kurumu. Accessed 01 Feb 2019.

11. Korkmaz, Ö., \& Develi, A. (2012). Türkiye'de Birincil Enerji Kullanımı, Üretimi ve Gayri Safi Yurt İçi Hasıla (GSYİH) Arasındaki İlişki. Dokuz Eylül Üniversitesi İktisadi ve İdari Bilimler Fakültesi Dergisi, 27(2), 25.

12. Lise, W., \& Van Montfort, K. (2005). Energy consumption and GDP in Turkey: Is there a co-integration relationship?, In EcoMod 2005 interantional conference on policy modeling, İstanbul, Turkey.

13. TÜIK. Temel İstatistikler, Ulusal Hesaplar - Harcama Yöntemi ile GSYH - Gayrisafi yurtiçi hasıla, harcama yöntemiyle zincirlenmiş hacim, endeks ve değişim oranları, 1998-2017. http://www.tuik.gov.tr/UstMenu.do?metod=temelist. Türkiye İstatistik Kurumu. Accessed 01 Feb 2019.

14. World Bank Open Data. GDP (constant 2010 US\$). https://data.worldbank.org/indicator/NY.GDP.MKTP.KD?end=2017\&locations=TR\&start=1972\&view $=$ chart. World Bank. Accessed $01 \mathrm{Feb} 2019$.

15. TCMB. Elektronik Veri Dağıtım Sistemi. Kurlar-Döviz kurları. Türkiye Cumhuriyeti Merkez Bankas1. https://evds2.tcmb.gov.tr/index.php?/evds/serieMarket/\#collapse_2. Türkiye Cumhuriyeti Merkez Bankas1. Accessed 01 Feb 2019.

16. EIA. Petroleum \& other liquids - Data. https://www.eia.gov/dnav/pet/hist/RWTCD.htm. U.S. Energy Information Administration. Accessed 01 Feb 2019.

Open Access This chapter is licensed under the terms of the Creative Commons Attribution 4.0 International License (http://creativecommons.org/licenses/by/4.0/), which permits use, sharing, adaptation, distribution and reproduction in any medium or format, as long as you give appropriate credit to the original author(s) and the source, provide a link to the Creative Commons license and indicate if changes were made.

The images or other third party material in this chapter are included in the chapter's Creative Commons license, unless indicated otherwise in a credit line to the material. If material is not included in the chapter's Creative Commons license and your intended use is not permitted by statutory regulation or exceeds the permitted use, you will need to obtain permission directly from the copyright holder.

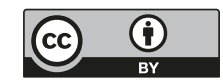

